EGU21-8969, updated on 10 May 2021

https://doi.org/10.5194/egusphere-egu21-8969

EGU General Assembly 2021

(c) Author(s) 2021. This work is distributed under

the Creative Commons Attribution 4.0 License.

\title{
Greenhouse gas balance of open peatlands is globally governed by soil water content and archaeal abundance
}

\author{
Sandeep Thayamkottu' ${ }^{1}$, Jaan Pärn ${ }^{1}$, Mohammad Bahram ${ }^{2,3}$, Mikk Espenberg ${ }^{1}$, Leho Tedersoo ${ }^{3,4}$, \\ Ülo Niinemets ${ }^{5}$, and Ülo Mander ${ }^{1}$ \\ ${ }^{1}$ Department of Geography, Institute of Ecology and Earth Sciences, University of Tartu, Vanemuise 46, 51014, Tartu, \\ Estonia \\ ${ }^{2}$ Department of Ecology, Swedish University of Agricultural Sciences, Ulls väg 16, 756 51, Uppsala, Sweden \\ ${ }^{3}$ Department of Botany, Institute of Ecology and Earth Sciences, University of Tartu, 40 Lai St. Tartu, Estonia \\ ${ }^{4}$ Natural History Museum, University of Tartu, Vanemuise St. 46, 51014, Tartu, Estonia \\ ${ }^{5}$ Institute of Agricultural \& Environmental Sciences, Estonian University of Life Sciences, Kreutzwaldi 1, 51006 Tartu, Estonia
}

There is a general consensus that peatlands are the source of about $10 \%$ of the global $\mathrm{CO}_{2}, \mathrm{CH}_{4}$ and $\mathrm{N}_{2} \mathrm{O}$ greenhouse gas (GHG) emissions. Yet, our knowledge about underlying processes and environmental factors that regulate the GHG are limited. Here, we found that the GHG balance of $\mathrm{CO}_{2}, \mathrm{CH}_{4}$ and $\mathrm{N}_{2} \mathrm{O}$ in 48 open peatland sites on five continents can be predicted by a model that incorporates soil water content (SWC) and archaeal abundance. We used our global database (2011-2019) on peat characteristics and field-measured soil respiration (ER), $\mathrm{CH}_{4}$ and $\mathrm{N}_{2} \mathrm{O}$ emissions. Furthermore, we used the gross primary productivity (GPP) dataset by Running, Mu \& Zhao (2015) on the basis of satellite data from the Moderate Resolution Imaging Spectrometer (MODIS) sensors alongside the ER to derive net ecosystem exchange (NEE) of carbon. The GHG balance follows SWC along a bell-shaped curve and increases with archaeal abundance and decomposition rate of peat-forming plant species. Thus, the net GHG emission peaks at intermediate SWC. These factors combined explains $61.9 \%$ (adjusted $\mathrm{R}^{2}=0.587$ ) of $\mathrm{GHG}$ balance and most of this variance is made up by the NEE of carbon (adjusted $R^{2}=0.97$ ). 